\title{
Change in symptoms of hypertensive patients after referral to hospital clinic
}

\author{
C. J. Bulpitt, C. T. Dollery, and S. Carne \\ From the London School of Hygiene and Tropical Medicine, the Royal Postgraduate Medical School, London, \\ and the Grove Health Centre, London
}

At their first visit to a hospital clinic 178 patients referred with a diagnosis of hypertension were given a self-administered questionnaire. They received a similar questionnaire 12 months later. Of the 178 patients 99 were not initially on treatment. Similarly 78 normotensive subjects were drawn randomly from the local population and sent a second questionnaire 10 months later. The symptoms at the first visit of the normotensive controls, the untreated hypertensive patients, and 477 patients on long-term treatment in the hypertension clinic were compared. Treated and untreated hypertensive patients complained more of nocturia and also of unsteadiness either on standing or in the morning. Treated hypertensives complained more of sleepiness, dry mouth, diarrhoea, and, in men, impotence and failure of ejaculation. Similarly, untreated hypertensives complained of excessive depression, blurred vision, and waking headache.

Fifty-five of the normotensive subjects and 110 of the newly referred hypertensive patients responded to the second questionnaire. The proportions losing and gaining symptoms were calculated together with the proportions always complaining and never complaining of a symptom. Hypertensive patients tended to lose the complaints of unsteadiness and headache but to gain the symptoms of vivid dreams, a slow walking pace, and diarrhoea. The net improvement for a symptom was defined as the excess of patients who lost a symptom over those who gained the symptom, expressed as a percentage. Over the follow-up period the control subjects had a net improvement averaged over 14 symptoms of $+2 \cdot 4$ per cent. A similar result was obtained for the hypertensive patients of $+2 \cdot 0$ per cent, the symptoms lost being balanced by those gained.

The changes in symptoms with time were related to the changes in blood pressure and it is suggested that only headache, 'unsteadiness, lightheadedness, or faintness' and nocturia can actually result from raised blood pressure and then only in a proportion of patients complaining of these symptoms.

Treating mild hypertension is expected to reduce morbidity and mortality and also perhaps symptoms. On the other hand, the patients have to take medicine daily which may produce side effects. To provide more information on the symptoms caused by hypotensive therapy we devised a self-administered questionnaire on those symptoms thought to be related to the level of blood pressure and on those of the known side effects of hypotensive drugs (Bulpitt, Dollery, and Carne, 1974). It included questions on waking headache; nocturia; weakness of the limbs; walking pace; sleepiness; hours of sleep; unsteadiness; dry mouth; diarrhoea; frequency of defaecation; depression; and, in men, impotence, failure of ejaculation, and the frequency of sexual intercourse.

Received 11 July 1975.
The present paper compares the symptoms of normal controls and hypertensive patients newly referred to hospital as recorded in the questionnaires at their first visit and after 10 to 12 months. The results are compared with a previous survey of hospital patients on long-term treatment (Bulpitt and Dollery, 1973).

\section{Methods}

Three surveys were conducted. Questionnaires were given, firstly, to 582 patients on long-term treatment who attended the Hammersmith Hospital hypertension clinic over a three-month period; secondly, to 212 patients with hypertension newly referred to the corresponding medical outpatients over a one-year period; and, thirdly, to 173 persons randomly selected from a local general practice register. The 582 patients were sent a 
questionnaire by post and asked to bring it completed at their next hospital visit: $105(18 \%)$ either failed to attend for an appointment or failed to complete the questionnaire. Patients who did not receive the questionnaire were excluded from the study population only if the questionnaire was 'returned to sender'. People in the general practice group were asked to complete the questionnaireandattend the practice surgery for measurement of their blood pressure. Despite one postal reminder only $88(51 \%)$ returned the questionnaire. The 212 'new' patients were given the questionnaire to take away at the time of their first hospital visit. When necessary one reminder was sent: $178(84 \%)$ returned the questionnaire. Details of drug treatment and blood pressure were added to the information derived from the questionnaire. In the new patient and general practice groups the following questions, to be answered 'yes' or 'no', were added: (The other questions have been published elsewhere (Bulpitt et al., 1974).)

Are you often troubled by a blocked or runny nose?

Compared to other men (women) of your age, are your powers of concentration better than average? Same as average? Worse than average?

Within the last three months have you often been troubled by vivid dreams or nightmares?

Within the last three months have you often felt sick or vomited?

Seventy-eight of the 88 general practice subjects were neither hypertensive nor on hypotensive drugs and 99 of the 178 new patients were not on treatment. The questionnaire was sent a second time on average 10 to 12 months later to the general practice subjects and to the hospital new patients. The response rate from the 88 general practice subjects was 75 per cent: one had died, two had moved, and 21 failed to reply. The response rate from the $\mathbf{1 7 8}$ hospital new patients was 66 per cent. Four had died, eight moved, and 56 failed to reply (response rates confined to those who had not moved).

\section{Statistical methods}

The Fig. represents the results obtained when giving the same question to $N$ patients on two occasions; ' $a$ '

\begin{tabular}{|c|c|c|}
\hline & \multicolumn{2}{|c|}{ Second answer } \\
\hline & No symptom & Symptom present \\
\hline No symptom & $\mathbf{a}$ & b \\
\hline Symptom present & c & d \\
\hline
\end{tabular}

FIG. Assessment of repeatability patients do not have the symptom on either occasion, ' $d$ ' patients have the symptom on both occasions, ' $b$ ' patients gain the symptom on the second questionnaire, and ' $c$ ' patients lose the symptom. Intuitive measures of repeatability, for example $(a+d) N$, vary with the prevalence of the symptom, and therefore repeatability was defined as $1-(\mathrm{bc} / \mathrm{ad})$ (R. G. Carpenter, 1975, personal communication). This measure will equal zero when the repeatability is due entirely to chance, and will equal 1 when $b+c=0$. In practical terms, however, repeatability cannot be calculated when either $a, b, c$, or $\mathrm{d}=0$.

\section{Results}

\section{Relationship between symptoms, disease, and receiving treatment}

Table 1 shows a comparison of the complaints recorded on the first questionnaire by the normotensive subjects, the hypertensive patients on longterm treatment, and the untreated hypertensive patients. The results of a $2 \times n \chi^{2}$ to detect any significant differences between the three groups are given in the last column. When a significant result was obtained two of the columns were pooled and compared with the remaining column. When the symptom was considered to be a side effect of treatment-for example, dry mouth, diarrhoea, sleepiness, impotence, and failure of ejaculationthe treated group was compared with the untreated and normotensive patients. When a symptom was thought to be associated with hypertension independent of treatment-for example, nocturia or faintness-the hypertensive groups were compared with the normotensive subjects. Waking headache, blurred vision, and depression appeared to be symptoms predominantly of untreated hypertension and were compared with the normotensive plus treated group.

Dry mouth, impotence, and failure of ejaculation appeared to be associated with therapy and occurred mainly in the group receiving treatment $(P<0.001$ for each comparison). A similar result was found with sleepiness $(P<0.01)$ and diarrhoea $(P<0.05)$. Nocturia and faintness occurred predominantly in the hypertensive groups, with or without treatment ( $P<0.001$ for both symptoms). The untreated hypertensives suffered more from waking headache $(P<0.001)$, depression $(P<0.01)$, and blurred vision $(P<0.05)$. A slow walking pace occurred most often in the treated group and was intermediate in the untreated hypertensive patients. This was also true for diarrhoea and sleepiness. The relation between individual drugs and these symptoms has already been reported (Bulpitt and Dollery, 1973). 
TABLE 1 Complaints in normotensive subjects, untreated hypertensive new patients, and long-term treated hypertensive patients. Asterisks within table refer to $\chi^{2}$ comparisons between one result and the results underlined in other columns

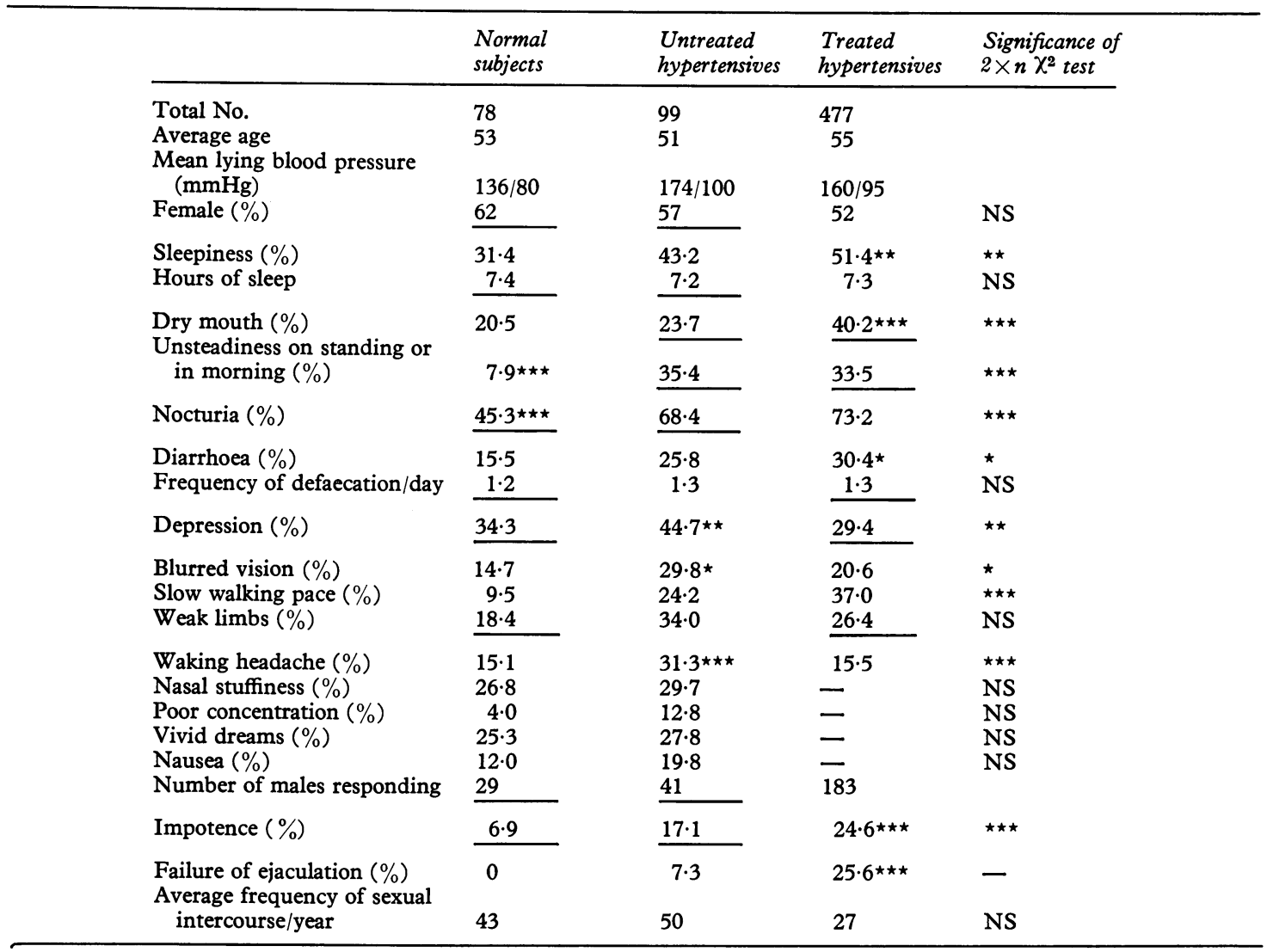

$\star P<0.05 . \star \star P<0.01 . \star \star \star P<0.001$.

$\mathrm{NS}=$ not significant.

Conversion: Traditional to SI Units-1 $\mathrm{mmHg} \approx 0.133 \mathrm{kPa}$.

Change in symptoms over 10 -month period in normotensive subjects

Table 2 shows the changes in symptoms of 55 normotensive general practice subjects whose initial diastolic blood pressure was less than $100 \mathrm{~mm} \mathrm{Hg}(13.3 \mathrm{kPa})$ and who did not receive hypotensive drugs (including diuretics and adrenergic beta-blocking drugs). Listed is the proportion of subjects who never had a particular symptom, the proportion of subjects who complained on both occasions, and the proportion of those who gained or lost the symptom. Also given are the repeatability of the questions as defined above and the proportion of subjects who showed a net improvement, where net improvement equals the proportion of patients losing a symptom less the proportion of those gaining the symptom. The net improvement for the symptoms ranged from $-6 \cdot 2$ per cent (nasal stuffiness) to 10.0 per cent (sleepiness). The average net improvement was 2.4 per cent. The symptoms most often lost were sleepiness $(14.0 \%)$ and depression $(10.6 \%)$. The symptoms most often gained were nasal stuffiness $(8.3 \%)$ and weakness of the limbs $(7 \cdot 4 \%)$. The repeatability of 13 single questions was equal to or greater than 0.95. Three symptoms-morning unsteadiness, faintness, or light-headedness; faintness on standing; and headache on waking in the morning-required more than one question to be answered, and the repeatability was correspondingly lower $(0 \cdot 87$ to $0 \cdot 94)$.

Table 3 shows the mean change in quantitative variables over a 10 -month period in 55 normotensive subjects. Over this period there was little change in the average hours slept, and frequency of defaecation, nocturia, or sexual intercourse. 
TABLE 2 Percentage change in symptoms in 55 normotensive subjects over 10-month period

\begin{tabular}{|c|c|c|c|c|c|c|}
\hline Symptoms & $\begin{array}{l}\text { Symptom } \\
\text { never present } \\
(\%)\end{array}$ & $\begin{array}{l}\text { Symptom } \\
\text { always present } \\
(\%)\end{array}$ & $\begin{array}{l}\text { Symptom } \\
\text { lost } \\
(\%)\end{array}$ & $\begin{array}{l}\text { Symptom } \\
\text { gained } \\
(\%)\end{array}$ & $\begin{array}{l}\text { Net } \\
\text { improvement } \\
(\%)\end{array}$ & Repeatability \\
\hline $\begin{array}{l}\text { Unsteadiness or faintness } \\
\text { Sleepiness } \\
\text { Weakness in limbs } \\
\text { Headaches } \\
\text { Blurred vision } \\
\text { Depression } \\
\text { Diarrhoea } \\
\text { Dry mouth } \\
\text { Nasal stuffiness } \\
\text { Nocturia } \\
\text { Slow walking pace } \\
\text { Poor concentration } \\
\text { Nausea } \\
\text { Vivid dreams } \\
\text { Average }\end{array}$ & $\begin{array}{l}85 \cdot 2 \\
66 \cdot 0 \\
75 \cdot 9 \\
60 \cdot 8 \\
86 \cdot 8 \\
61 \cdot 7 \\
80 \cdot 0 \\
80 \cdot 0 \\
66 \cdot 7 \\
47 \cdot 2 \\
90 \cdot 2 \\
92 \cdot 2 \\
84 \cdot 9 \\
77 \cdot 8 \\
-\end{array}$ & $\begin{array}{r}3 \cdot 7 \\
16 \cdot 0 \\
11 \cdot 1 \\
27 \cdot 5 \\
7 \cdot 6 \\
21 \cdot 3 \\
10 \cdot 0 \\
10 \cdot 0 \\
22 \cdot 9 \\
47 \cdot 2 \\
5 \cdot 9 \\
3 \cdot 9 \\
7 \cdot 6 \\
11 \cdot 1 \\
-\end{array}$ & $\begin{array}{r}9 \cdot 2 \\
14 \cdot 0 \\
5 \cdot 7 \\
5 \cdot 9 \\
3 \cdot 8 \\
10 \cdot 6 \\
6 \cdot 0 \\
8 \cdot 0 \\
2 \cdot 1 \\
1 \cdot 9 \\
3 \cdot 9 \\
1 \cdot 9 \\
3 \cdot 8 \\
9 \cdot 3 \\
-\end{array}$ & $\begin{array}{l}1 \cdot 8 \\
4 \cdot 0 \\
7 \cdot 4 \\
5 \cdot 9 \\
1.9 \\
6 \cdot 4 \\
4 \cdot 0 \\
2 \cdot 0 \\
8 \cdot 3 \\
3 \cdot 8 \\
0 \\
1.9 \\
3 \cdot 8 \\
1.9 \\
-\end{array}$ & $\begin{array}{c}7 \cdot 4 \\
10 \cdot 0 \\
-1 \cdot 7 \\
0 \\
1 \cdot 9 \\
4 \cdot 2 \\
2 \cdot 0 \\
6 \cdot 0 \\
-6 \cdot 2 \\
-1 \cdot 9 \\
3 \cdot 9 \\
0 \\
0 \\
7 \cdot 4 \\
2 \cdot 4\end{array}$ & $\begin{array}{l}0.95 \\
0.95 \\
0.95 \\
0.98 \\
0.99 \\
0.95 \\
0.97 \\
0.98 \\
0.99 \\
1.00 \\
- \\
0.99 \\
0.98 \\
0.98 \\
0.97\end{array}$ \\
\hline $\begin{array}{l}\text { Multiple questions: } \\
\text { Morning faintness } \\
\text { Faintness on standing } \\
\text { Waking headaches }\end{array}$ & $\begin{array}{l}98 \cdot 18 \\
90.90 \\
83.63\end{array}$ & $\begin{array}{l}0 \\
1 \cdot 82 \\
3 \cdot 63\end{array}$ & $\begin{array}{l}0 \\
5 \cdot 45 \\
7 \cdot 27\end{array}$ & $\begin{array}{l}1.81 \\
1.82 \\
5.45\end{array}$ & $\begin{array}{r}-1.81 \\
3.63 \\
1.82\end{array}$ & $\begin{array}{l}\overline{0.94} \\
0.87\end{array}$ \\
\hline $\begin{array}{l}\text { Males : } \\
\text { Impotence } \\
\text { Failure of ejaculation }\end{array}$ & $\begin{array}{c}94 \cdot 1 \\
100\end{array}$ & $\begin{array}{l}0 \\
0\end{array}$ & $\begin{array}{l}0 \\
0\end{array}$ & $\begin{array}{l}5 \cdot 9 \\
0\end{array}$ & $\begin{array}{c}-5 \cdot 9 \\
0\end{array}$ & - \\
\hline
\end{tabular}

^Based on replies from 17 men.

TABLE 3 Mean change in quantitative information over 10-month period for 55 normotensive subjects and over 12-month period for 110 hypertensive new patients (figures in parentheses are numbers contributing to mean)

\begin{tabular}{|c|c|c|c|c|}
\hline & $\begin{array}{l}\text { Normotensive } \\
\text { subjects }\end{array}$ & $S E M$ & $\begin{array}{l}\text { Hypertensive } \\
\text { new patients }\end{array}$ & $S E M$ \\
\hline Hours of sleep & $-0 \cdot 14(50)$ & 0.09 & $0.07(103)$ & $0 \cdot 11$ \\
\hline $\begin{array}{l}\text { Frequency of } \\
\text { defaecation/day }\end{array}$ & $-0.04(52)$ & 0.04 & $-0.05(109)$ & 0.05 \\
\hline $\begin{array}{l}\text { Frequency of } \\
\text { nocturia } \\
\text { (times/night) }\end{array}$ & $0.03(53)$ & 0.05 & $0 \cdot 12(109)$ & 0.08 \\
\hline $\begin{array}{l}\text { Frequency of } \\
\text { sexual intercourse } \\
\text { (men, times/year) }\end{array}$ & $2 \cdot 5$ & $4 \cdot 7$ & $-2 \cdot 4 \quad(49)$ & 3.9 \\
\hline
\end{tabular}

SEM $=$ standard error of mean.

Change in symptoms over 12-month period in new hypertensive patients

Table 4 shows the change in symptoms of 110 new hypertensive patients referred with a diagnosis of hypertension. The net improvements for unsteadiness $(21.5 \%)$, headache $(13.6 \%)$, unsteadiness on standing $(16 \%)$, and waking headache $(16 \%)$ were above the range of results in the control subjects $(-6$ to $+10 \%)$, and the net improvements for nocturia $(-9.2 \%)$ and vivid dreams $(-9.6 \%)$ were less than expected. Similarly, repeatability was below the expected range for all single questions apart from nocturia and slow walking pace. The symptom of vivid dreams was gained by $17 \cdot 3$ per cent, sleepiness by 15.4 per cent, and weakness of the limbs by 14.3 per cent of the patients. On the other hand, unsteadiness was lost in 25.2 per cent, headache in 19.4 per cent, and nasal stuffiness in 16.0 per cent of patients. The average net improvement $(2 \cdot 0 \%)$ for these 14 symptoms was similar to the average for the normal controls $(+2 \cdot 4 \%)$.

Table 3 shows the average changes in quantitative variables in the 110 new hypertensive patients. The mean results do not differ significantly from the averages for the normotensive subjects.

\section{Change in treatment over one-year period in new hypertensive patients}

Table 5 gives the initial and final therapy in 110 new hypertensive patients. Twenty-four patients $(22 \%)$ had no treatment and in $32(29 \%)$ the treatment was not greatly altered over the year. When treatment was changed the number starting any one particular treatment was never greater than 12 . 
TABLE 4 Percentage change in symptoms in 110 new hypertensive patients over a 12-month period

\begin{tabular}{|c|c|c|c|c|c|c|}
\hline Symptoms & $\begin{array}{l}\text { Symptom } \\
\text { never present } \\
(\%)\end{array}$ & $\begin{array}{l}\text { Symptom } \\
\text { always present } \\
(\%)\end{array}$ & $\begin{array}{l}\text { Symptom } \\
\text { lost } \\
(\%)\end{array}$ & $\begin{array}{l}\text { Symptom } \\
\text { gained } \\
(\%)\end{array}$ & $\begin{array}{l}\text { Net } \\
\text { improvement } \\
(\%)\end{array}$ & Repeatability \\
\hline $\begin{array}{l}\text { Unsteadiness or faintness } \\
\text { Sleepiness } \\
\text { Weakness in limbs } \\
\text { Headache } \\
\text { Blurred vision } \\
\text { Depression } \\
\text { Diarrhoea } \\
\text { Dry mouth } \\
\text { Nasal stuffiness } \\
\text { Nocturia } \\
\text { Slow walking pace } \\
\text { Poor concentration } \\
\text { Nausea } \\
\text { Vivid dreams } \\
\text { Average }\end{array}$ & $\begin{array}{l}36 \cdot 4 \\
35 \cdot 6 \\
45 \cdot 7 \\
29 \cdot 1 \\
62 \cdot 1 \\
43 \cdot 1 \\
66 \cdot 3 \\
56 \cdot 9 \\
54 \cdot 0 \\
24 \cdot 1 \\
58 \cdot 9 \\
77 \cdot 6 \\
71 \cdot 2 \\
62 \cdot 5 \\
-\end{array}$ & $\begin{array}{r}34 \cdot 6 \\
35 \cdot 6 \\
24 \cdot 8 \\
45 \cdot 6 \\
18 \cdot 5 \\
33 \cdot 3 \\
13 \cdot 3 \\
24 \cdot 5 \\
20 \cdot 0 \\
61 \cdot 1 \\
26 \cdot 2 \\
9 \cdot 4 \\
9 \cdot 6 \\
12 \cdot 5 \\
-\end{array}$ & $\begin{array}{r}25 \cdot 2 \\
13 \cdot 5 \\
15 \cdot 2 \\
19 \cdot 4 \\
11 \cdot 7 \\
13 \cdot 7 \\
8 \cdot 2 \\
7 \cdot 8 \\
16 \cdot 0 \\
5 \cdot 6 \\
4 \cdot 7 \\
6 \cdot 5 \\
12 \cdot 5 \\
7 \cdot 7 \\
-\end{array}$ & $\begin{array}{r}3 \cdot 7 \\
15 \cdot 4 \\
14 \cdot 3 \\
5 \cdot 8 \\
7 \cdot 8 \\
9 \cdot 8 \\
12 \cdot 2 \\
10 \cdot 8 \\
10 \cdot 0 \\
9 \cdot 3 \\
10 \cdot 3 \\
6 \cdot 5 \\
6 \cdot 7 \\
17 \cdot 3 \\
-\end{array}$ & $\begin{array}{r}21.5 \\
-1.9 \\
1.0 \\
13.6 \\
3.9 \\
3.9 \\
-4 \cdot 1 \\
-2.9 \\
6.0 \\
-3.7 \\
-5.6 \\
0.0 \\
5.8 \\
-9.6 \\
2.0\end{array}$ & $\begin{array}{l}0.93 \\
0.84 \\
0.83 \\
0.92 \\
0.92 \\
0.91 \\
0.89 \\
0.94 \\
0.85 \\
0.97 \\
0.97 \\
0.94 \\
0.88 \\
0.83 \\
0.90\end{array}$ \\
\hline $\begin{array}{l}\text { Multiple questions: } \\
\text { Morning faintness } \\
\text { Faintness on standing } \\
\text { Waking headache }\end{array}$ & $\begin{array}{l}65 \cdot 45 \\
55 \cdot 45 \\
65 \cdot 5\end{array}$ & $\begin{array}{l}10 \cdot 0 \\
13 \cdot 63 \\
10 \cdot 9\end{array}$ & $\begin{array}{l}17 \cdot 27 \\
23.63 \\
20 \cdot 0\end{array}$ & $\begin{array}{l}7 \cdot 27 \\
7 \cdot 27 \\
3 \cdot 6\end{array}$ & $\begin{array}{l}10 \cdot 0 \\
16 \cdot 36 \\
16 \cdot 4\end{array}$ & $\begin{array}{l}0.80 \\
0.77 \\
0.90\end{array}$ \\
\hline $\begin{array}{l}\text { Males^: } \\
\text { Failure of ejaculation } \\
\text { Impotence }\end{array}$ & $\begin{array}{l}90.0 \\
80.9\end{array}$ & $\begin{array}{r}2 \cdot 0 \\
10 \cdot 6\end{array}$ & $\begin{array}{l}4.0 \\
4.3\end{array}$ & $\begin{array}{l}4 \cdot 0 \\
4 \cdot 3\end{array}$ & $\begin{array}{l}0 \\
0\end{array}$ & $\begin{array}{l}0.91 \\
0.98\end{array}$ \\
\hline
\end{tabular}

*Based on replies from 52 men.

Change in blood pressure according to change in symptoms

Sixty-four of the 110 new hypertensive patients had a lying blood pressure recorded at the beginning and at the end of the 12-month follow-up period. The fall in lying diastolic (FLD) and systolic (FLS) pressure between the first and last visit was computed together with the average of the two systolic readings (AS) and the two diastolic measurements (AD). The mean $( \pm$ SEM) $A D$ was $99 \pm 2 \mathrm{mmHg}$ $(13.2 \pm 0.3 \mathrm{kPa})$. Similarly the mean AS was
$171 \pm 4 \mathrm{mmHg}(22.7 \pm 0.5 \mathrm{kPa})$; mean FLD $16 \pm 2$ $\mathrm{mmHg}(2.1 \pm 0.3 \mathrm{kPa})$; and the mean FLS $40 \pm 4$ $\mathrm{mmHg}(5 \cdot 3 \pm 0 \cdot 5 \mathrm{kPa})$.

Table 6 shows the mean FLD, FLS, AD, and AS according to whether a particular symptom was never present, always present, lost, or gained.

If a symptom is relieved by lowering the blood pressure the patients losing the symptom should show a high mean FLS and mean FLD. The 11 patients losing the complaint of headache had a high mean fall in systolic pressure of $60 \mathrm{mmHg}$

TABLE 5 Changes in therapy in 110 new hypertensive patients after one year

\begin{tabular}{|c|c|c|c|c|c|c|}
\hline Initial treatment & $\begin{array}{l}\text { Final treatment } \\
\text { None }\end{array}$ & $\begin{array}{l}\text { Diuretic } \\
\text { alone }\end{array}$ & $\begin{array}{l}\text { Methyldopa } \\
\pm \text { diuretic }\end{array}$ & $\begin{array}{l}\text { Bethanidine } \\
\pm \text { diuretic }\end{array}$ & $\begin{array}{l}\text { Propranolol } \\
\pm \text { diuretic }\end{array}$ & $\begin{array}{l}\text { Other } \\
\text { combination }\end{array}$ \\
\hline None & 24 & 12 & 9 & 1 & 5 & 5 \\
\hline Diuretic alone & 0 & 7 & 5 & 0 & 1 & 1 \\
\hline Methyldopa \pm diuretic & 2 & 3 & 18 & 0 & 0 & 6 \\
\hline Bethanidine \pm diuretic & 0 & 0 & 1 & 1 & 0 & 2 \\
\hline Propranolol \pm diuretic & 0 & 0 & 0 & 0 & 1 & 0 \\
\hline Other combination & 0 & 1 & 0 & 0 & 0 & 5 \\
\hline
\end{tabular}


TABLE 6 Mean lying systolic pressure ( $L S P$ ), lying diastolic pressure ( $L D P$ ), fall in LSP, and fall in LDP, in $\mathrm{mmHg}$, for 64 patients referred with hypertension over 12-month period. Means calculated only for 5 or more patients

\begin{tabular}{|c|c|c|c|c|c|c|c|c|c|c|c|c|}
\hline \multirow{2}{*}{ Symptom } & \multicolumn{4}{|c|}{ Symptom never present } & \multirow[b]{2}{*}{ No. } & \multicolumn{4}{|c|}{ Symptom always present } & \multirow[b]{2}{*}{ No. } & \multicolumn{2}{|c|}{ Symptom lost } \\
\hline & $\begin{array}{l}\text { Average } \\
\text { LSP }\end{array}$ & $\begin{array}{l}\text { Average } \\
L D P\end{array}$ & $\begin{array}{l}\text { Fall } \\
L S P\end{array}$ & $\begin{array}{l}\text { Fall } \\
L D P\end{array}$ & & $\begin{array}{l}\text { Average } \\
\text { LSP }\end{array}$ & $\begin{array}{l}\text { Average } \\
\text { LDP }\end{array}$ & $\begin{array}{l}\text { Fall } \\
\text { LSP }\end{array}$ & $\begin{array}{l}\text { Fall } \\
L D P\end{array}$ & & $\begin{array}{l}\text { Average } \\
\text { LSP }\end{array}$ & $\begin{array}{l}\text { Averag } \\
L D P\end{array}$ \\
\hline Unsteadiness & 165 & 99 & 41 & 21 & 21 & 169 & 98 & 39 & 14 & 23 & 174 & 100 \\
\hline Headache & 167 & 98 & 35 & 17 & 18 & 165 & 98 & 32 & 10 & 28 & 176 & 104 \\
\hline Blurred vision & 167 & 99 & 38 & 18 & 40 & 172 & 100 & 38 & 7 & 10 & 177 & 102 \\
\hline Depression & 170 & 99 & 27 & 20 & 27 & 167 & 96 & 41 & 11 & 18 & 167 & 103 \\
\hline Dry mouth & 164 & 97 & 41 & 17 & 37 & 179 & 105 & 45 & 19 & 12 & 174 & 105 \\
\hline Nocturia & 159 & 97 & 26 & 15 & 14 & 173 & 100 & 42 & 16 & 37 & $\longrightarrow$ & $\longrightarrow$ \\
\hline Sleepiness & 163 & 97 & 37 & 16 & 27 & 176 & 103 & 40 & 12 & 19 & 171 & 98 \\
\hline Weak limbs & 166 & 99 & 38 & 18 & 30 & 175 & 101 & 35 & 10 & 17 & 164 & 95 \\
\hline Nausea & 169 & 100 & 45 & 20 & 44 & $\longrightarrow$ & - & - & - & 4 & 166 & 97 \\
\hline Vivid dreams & 170 & 101 & 41 & 18 & 40 & 159 & 93 & 41 & 17 & 7 & $\longrightarrow$ & $\longrightarrow$ \\
\hline Poor concentration & 170 & 99 & 38 & 15 & 46 & 171 & 96 & 33 & 9 & 8 & 一 & - \\
\hline Nasal stuffiness & 171 & 99 & 47 & 18 & 35 & 174 & 101 & 44 & 16 & 8 & 163 & 99 \\
\hline Slow walking pace & 166 & 100 & 36 & 17 & 33 & 179 & 100 & 43 & 8 & 18 & - & 一 \\
\hline $\begin{array}{l}\text { Diarrhoea } \\
\text { Unsteadiness on }\end{array}$ & 168 & 100 & 40 & 16 & 43 & 167 & 91 & 17 & 2 & 9 & $\longrightarrow$ & 一 \\
\hline on standing & 170 & 100 & 45 & 20 & 31 & 167 & 97 & 24 & 9 & 12 & 170 & 98 \\
\hline Unsteadiness in & & & & & & & & & & & & \\
\hline morning & 170 & 100 & 43 & 19 & 40 & 166 & 99 & 25 & 7 & 7 & 167 & 95 \\
\hline Waking headache & 170 & 99 & 37 & 18 & 33 & 166 & 95 & 29 & 10 & 8 & 172 & 104 \\
\hline
\end{tabular}

Conversion factor from Traditional Units to SI Units: $1 \mathrm{mmHg} \approx 0.133 \mathrm{kPa}$.

$(8.0 \mathrm{kPa})$ which was compared with the mean drop for other patients, $34 \mathrm{mmHg}(4.5 \mathrm{kPa})$. The difference between the means was significant at the 5 per cent level. A similar high systolic drop $(55 \mathrm{mmHg}[7.3 \mathrm{kPa}])$ was noted with 14 patients losing a waking headache. The fall in diastolic pressure did not reach statistical significance. The average fall in systolic pressure of $54 \mathrm{mmHg}$ $(7.2 \mathrm{kPa})$ in 8 patients losing blurring of vision did not achieve statistical significance.

When a symptom is a side effect of a potent hypotensive agent the gain of a symptom may be accompanied by an increased average FLD and FLS. The gain of sleepiness was accompanied by an increased mean FLD $(28 \mathrm{mmHg}(3.7 \mathrm{kPa})$ against $14 \mathrm{mmHg}(1.9 \mathrm{kPa}) ; \mathrm{P}<0.05)$. Similarly, a high average FLS and FLD was observed with patients developing poor power of mental concentration (FLS $63 \mathrm{mmHg}[8.4 \mathrm{kPa}]$ and FLD $24 \mathrm{mmHg}[3.2 \mathrm{kPa}])$.

\section{Discussion}

The differences between the untreated hypertensive patients and the controls may be due to one of at least four mechanisms: (1) a raised blood pressure; (2) the hypertensive patient's concept of symptoms he should expect; (3) the referring doctor's concept of hypertension-related symptoms which led him to the diagnosis; (4) psychoneurosis associated with hypertension. For example, a man with a headache reports the symptom to his doctor and the doctor suspects hypertension. The blood pressure is taken, found to be raised, the patient is informed that the headache is due to hypertension, and he is referred to hospital. The symptom may be due to the raised pressure or to other causes, but the prevalence of headache in hypertension-clinic patients is high since the blood pressure is often not taken and hypertension not diagnosed in patients without this symptom.

We must therefore examine headache, blurred vision, depression, unsteadiness, and nocturia to see if there is any evidence that they result from a high blood pressure, all five symptoms being in excess in the untreated hypertensive group. Headache and unsteadiness were relieved during the follow-up period, and the patients losing their headache had a significantly higher average fall in systolic pressure over this period. These symptoms may therefore be causally associated with high levels of blood pressure, whereas blurring of vision, depression, and nocturia were not relieved over the 12-month period, the net improvements in hypertensive patients being similar to those in control subjects. In treated patients the frequency of nocturia can be related to both blood pressure 


\begin{tabular}{|c|c|c|c|c|c|c|c|}
\hline \multicolumn{2}{|c|}{ Symptom lost } & \multirow[b]{2}{*}{ No. } & \multicolumn{4}{|c|}{ Symptom gained } & \multirow[b]{2}{*}{ No. } \\
\hline $\begin{array}{l}\text { Fall } \\
L S P\end{array}$ & $\begin{array}{l}\text { Fall } \\
L D P\end{array}$ & & $\begin{array}{l}\text { Average } \\
\text { LSP }\end{array}$ & $\begin{array}{l}\text { Average } \\
L D P\end{array}$ & $\begin{array}{l}\text { Fall } \\
\text { LSP }\end{array}$ & $\begin{array}{l}\text { Fall } \\
L D P\end{array}$ & \\
\hline 41 & 11 & 15 & - & 一 & - & - & 3 \\
\hline 60 & 22 & 11 & - & - & - & - & 1 \\
\hline 54 & 16 & 8 & - & 一 & 一 & 一 & 3 \\
\hline 35 & 13 & 8 & 172 & 100 & 32 & 13 & 8 \\
\hline 22 & 10 & 6 & 169 & 94 & 34 & 6 & 5 \\
\hline- & - & 4 & 162 & 99 & 51 & 11 & 7 \\
\hline 47 & 11 & 8 & 179 & 103 & 49 & 28 & 7 \\
\hline 47 & 17 & 8 & 172 & 100 & 56 & 19 & 7 \\
\hline 28 & 4 & 8 & - & - & - & - & 4 \\
\hline 一 & - & 4 & 169 & 100 & 43 & 16 & 10 \\
\hline- & - & 3 & 158 & 113 & 63 & 24 & 5 \\
\hline 23 & 8 & 10 & 165 & 102 & 35 & 22 & 5 \\
\hline 一 & 一 & 3 & 161 & 98 & 49 & 24 & 8 \\
\hline 一 & 一 & 2 & 一 & - & 一 & 一 & 4 \\
\hline 41 & 13 & 17 & 一 & - & 一 & 一 & 4 \\
\hline 36 & 7 & 12 & 165 & 99 & 45 & 20 & 5 \\
\hline 55 & 17 & 14 & - & - & - & - & 3 \\
\hline
\end{tabular}

and treatment (Bulpitt et al., 1974; Bulpitt and Dollery, 1974).

We suggest that raised blood pressure does indeed cause headache, and 'unsteadiness'. Headache and 'unsteadiness' are common in neurotic patients (Riseman and Weiss, 1930; Ayman and Pratt, 1931), and increase in hypertensive patients with the degree of psychoneurosis (Bulpitt, Hoffbrand, and Dollery, 1975). However, for psychoneurosis totally to explain the excessive complaints of headache, we should have to assume that neurosis is improved more when the systolic blood pressure is reduced by an average of $60 \mathrm{mmHg}(8.0 \mathrm{kPa})$ than when it is reduced by $34 \mathrm{mmHg}(4.5 \mathrm{kPa})$. Similarly if psychoneurosis is improved by treatment, why are the net improvements for headache $(13.6 \%)$ and 'unsteadiness' $(21 \cdot 5 \%)$ so much better than the net improvement for 'depression' (3.9\%)?

Table 1 indicates, however, that in hypertensive patients at least a half of waking headaches and a quarter of 'unsteadiness on stadding or in the morning' will be unrelated to the height of the untreated blood pressure.

The symptoms which increased during the follow-up of hypertensive patients were probably side effects of drug therapy. The net improvements in sleepiness $(-1.9$ against $+10.0 \%$ for controls), dry mouth $(-2.9$ against $+6.0 \%)$, diarrhoea
$(-4 \cdot 1$ against $+2 \cdot 0 \%)$, vivid dreams (-9.6 against $+7 \cdot 4 \%$ ), and slow walking pace ( -5.6 against $+3.9 \%$ ) were all worse in the hypertensive patients than in the control subjects. The failure to confirm, in the longitudinal studies, an association between treatment and impotence and failure of ejaculation in men was owing to the patients not being given adrenergic neurone-blocking drugs. Examination of blood pressure changes supported sleepiness as a side effect of treatment. Larger numbers are required to examine separate therapeutic groups and a larger survey has been started of all new patients attending two hypertension clinics over a period of two years.

The repeatability of the questions was satisfactory in the normotensive group and the index $1-(\mathrm{bc} / \mathrm{ad})$ acts as a standard, independent of prevalence, against which new questions can be judged. The lack of dependence on prevalence is an advantage of this index over other suggested measures of repeatability (Young, 1971; Zeiner-Henriksen, 1972). The index is slightly easier to compute than the measurement proposed by Rogot and Goldberg (1966), though their index can be computed if one cell is zero but not if a marginal total is zero. The average net improvement for all symptoms and both sexes expresses the change in symptomatic welfare of the patients. It is of interest that the normotensive controls showed a positive average net improvement of 2.4 per cent. In the hypertensive patients the relief of certain symptoms was balanced by a gain of side effects to give an average net improvement of 2.0 per cent.

The longitudinal approach with assessment of net improvement may help to establish a health status index (Fanshel and Bush, 1970), which may be used for establishing the benefits or otherwise of the drug treatment of hypertension. Information is being collected on the changes in mortality and morbidity to be expected from treatment (Veterans Administration Cooperative Study Group, 1970; Amery and de Schaepdrijver, 1973; Peart, 1973), and these data should be supplemented by validated, reproducible measures of the symptomatic wellbeing of patients.

The study was supported in part by a grant from the Department of Health and Social Security.

\section{References}

Amery, A., and De Schaepdrijver, A. (1973). Organization of a double-blind multicentre trial on antihypertensive therapy in elderly patients. European Working Party on High Blood Pressure in Elderly (E.W.P.H.E.). Clinical Science and Molecular Medicine, 45, 71S.

Ayman, D., and Pratt, J. H. (1931). Nature of the symptoms associated with essential hypertension. Archives of Internal Medicine, 47, 675. 
Bulpitt, C. J., and Dollery, C. T. (1973). Side effects of hypotensive agents evaluated by a self-administered questionnaire. British Medical fournal, iii, 485.

Bulpitt, C. J., Dollery, C. T., and Carne, S. (1974). A symptom questionnaire for hypertensive patients. fournal of Chronic Diseases, 27, 309.

Bulpitt, C. J., Hoffbrand, B. I., and Dollery, C. T. (1975). Somatic complaints in patients with psychoneurosis. In preparation.

Fanshel, S., and Bush, J. W. (1970). A health-status index and its application to health service outcomes. Operations Research, 18, 1021.

Peart, W. S. (1973). The organization of a multi-centre randomized control therapeutic trial for mild to moderate hypertension. Clinical Science and Molecular Medicine, 45, $67 \mathrm{~S}$.

Riseman, J. E. F., and Weiss, S. (1930). The symptomatology of arterial hypertension. American fournal of the Medical Sciences, 180, 47.
Rogot, E., and Goldberg, I. D. (1966). A proposedi ndex for measuring agreement in test-retest studies. Fournal of Chronic Diseases, 19, 991.

Veterans Administration Cooperative Study Group on Antihypertensive Agents (1970). Effects of treatment on morbidity in hypertension. Fournal of the American Medical Association, 213, 1143.

Young, D. W. (1971). Assessment of questions and questionnaires. Methods of Information in Medicine, 10, 222.

Zeiner-Henriksen, T. (1972). The repeatability at interview of symptoms of angina and possible infarction. Fournal of Chronic Diseases, 25, 407.

Requests for reprints to Dr. C. J. Bulpitt, Department of Medical Statistics and Epidemiology, London School of Hygiene and Tropical Medicine, Keppel Street, London WC1E 7HT. 